\title{
Isabel's Tragic Marriage in The Portrait of A Lady
}

\author{
Lei Zhang ${ }^{1}$ \\ ${ }^{1}$ School of Foreign Language Studies, Dalian Jiaotong University, Dalian, Liaoning 116028, China \\ *Corresponding author. Email: leiiris@163.com
}

\begin{abstract}
In The Portrait of A lady Henry James presents the character conflicts in three levels: the double-folded characters of the heroine Isabel Archer, her idea of ideal marriage and the cultural conflicts between Europe and America to provide the reasonableness and necessity for her marital tragedy. He highly praises Isabel for her strong belief in and persistent quest for her ideal and shows how difficult this quest is in the real world.
\end{abstract}

Keywords: character conflicts, double-folded characters, marital tragedy, quest

\section{INTRODUCTION}

With full contents, delicate psychological description and various vivid characters, The Portrait of A lady is considered as the early masterpiece of Henry James and one of the greatest novels in the American literature.

The lady in this novel is Isabel Archer, a slim and beautiful American girl whose parents are both dead, two elder sisters are married and she herself is brought to England by her aunt. In England, she comes across several proposals which are turned down by her and at last, she marries an American living in Italy Gilbert Osmond, but ends up with a marital tragedy.

The novel fully expresses Henry James's international theme-in the different cultural environment, American and European people's conflicts in mutual communication. This theme is tightly connected with the heroine Isabel Archer, and the entire novel puts emphasis on her characters. She is intelligent, attractive, independent and imaginative [1]. However, she is so idealistic and doesn't sense the plot that limits her choice. She respects the free and spiritual marriage, but does not know how cruel the reality is. Just as Henry James in his notebook speaks of Isabel: "The poor girl who has dreamed of freedom and nobleness and who finds herself in reality ground in the very mill of the conventional" [2] This paper starts from Isabel's characters, idea of marriage and her failure in the crossculture communication, and tries to analyse the multilayer conflicts and provides the reasonableness and necessity for her marital tragedy.

\section{ISABEL'S DOUBLE-FOLDED CHARACTERS}

Isabel, Henrietta and Goodwood are the models of American culture. They are frank, confident, brave and defiant against conventions. Distinct from the latter two, "the confidence at once innocent and dogmatic, the temper at once exciting and indulgent, the mixture of curiosity and fastidiousness, of vivacity and indifference, the desire to look very well and to be if possible, even better, the determination to see, to try, to know, the combination of the delicate, desultory, flamelike spirit and the eager and personal creature of conditions" [3] make her a delightful young enthusiast and full of zest for life. From her engagement with Osmond, we can divide her development of characters into two phases: The first is her recognition of the world. "She is attractive, innocent and intelligent", [1] and when she turns down Lord Warburton's proposal for marriage, Mr Touchett "put a little wind in her sails" [1] and promotes her to know well of the world. The second is her recognition of herself. Knowing the marriage is a failure, she introspects about herself, her husband and their marriage a lot and decides to adhere to the oath in order to meet the requirements of her husband. However, Pancy's marital affairs and the dying of Ralph make the conflicts fiercer and the base secret is disclosed. Their marriage goes to the tragedy at last, which provides a sufficient proof of Isabel's defect in characters. Just as a famous translator Zhao Luorui speaks of her as: Isabel has both the heroic virtue and 
the fatal drawback. She possesses double-folded characters.

In the first meet with Isabel on the lawn of the Gardencourt, Mr Touchett praises her beauty. She rises instantly with a blush yet not a refutation: "Oh, yes, of course, I'm lovely!" [3] Confidence gives her natural charm but can also traps her into conceit. Her marriage is the best example: she regards Osmond as "the first gentleman in Europe" [3] and she would "launch his boat for him and she would be his providence". [3] She adheres to her own opinion, ignoring relatives and friends' advice. Many of her senses are full of confidence, but also hide the conceit causing the marital failure.

Meanwhile, Isabel tries to judge things on her own, and things like freedom, liberty, independence and selfconfidence have always meant to Isabel to understand all the implications of such a discovery. When she appears on the lawn of Gardencourt, her abundant confidence, both in herself and in other strikes Ralph a lot. To her, liberty means to know everything, including all the possibilities ahead in order to choose freely, confidently, responsibly, as when she tells her aunt that she always likes to know things one shouldn't do "so as to choose" [4]. With these charming characters, suitors come rapidly and her refusal against them shows her independence. Lord Warburton causes her a "certain" fear and she reasons that marriage to a nobleman "might impose conditions and obligations inimical to her autonomy" [2]. From Caspar Goodwood, she shrinks again and again with overt fright; this straight young man from Boston is too direct and too insistent when at the end, under the splendid tree of Gardencourt, he will sweep Isabel into his arms and gives her the single kiss recorded in the book, like white lightening which suggests to her the compromises of passion, but severely threatens her individuality. When the passion decays, she still pulls together with independence.

Unfortunately, her independence often turns to arbitrariness subconsciously and foreshadows her tragic fate. One evidence comes from showing the pictures. When Ralph suggests to show them tomorrow because of dim light, Isabel looks disappointed-smiling and says: "If you please, I should like to see them just a little" [3] to ignore his wise advice which exposes her arbitrariness for the first time. Also, she doesn't intend to accept others' opinion which she believes inferior. When all the relatives and friends' discreet opposition to her marriage with Gilbert Osmond leaves even no great impression upon her, this dislike is not alarming to her, and she scarcely even regrets it afterwards: "I don't marry for my friends and relatives!" [3] She considers Mrs Touchett's idea toward her marriage as cold and shallow and "It is my duty to tell you, Aunt Lydia, but I don't think it my duty to explain to you, even if it were, I should be able, so please don't remonstrate!" [3] She cannot accept Ralph's attitude toward Osmond, and regards his words as "surely a kind of whimsical cover for a personal disappointment." [3] All these dogmatic actions lead her to the unsuccessful marriage.

\section{ISABEL'S IDEA OF MARRIAGE}

At beginning of the novel, Henry James tells readers that Isabel does not want to take marriage into consideration at present. But "deep in her soul-it was the deepest thing there-lay a belief that if a certain light should dawn she could give herself completely" [3]. What kind of light is it? The author thinks it comes from the holly sanctuary of marriage. This description gives readers a kind of conjecture about Isabel's marriage.

Isabel's first suitor is Caspar Goodwood. He was the son of a proprietor of well-known cotton-mill in Massachusetts - an American gentleman who had accumulated a considerable fortune in the exercise of this industry. With a judgement and a temper which, despite keen competition and languid years had kept their prosperity from dwindling. [3] $\mathrm{He}$ receives education at Harvard College, and he has thus "discovered in himself a sharp eye for the mystery of mechanics, and had invented an improvement in the cotton-spinning process" [3]. He himself becomes an excellent gentleman. However, to Isabel, "the straight young man" [1] is too direct and too insistent. He has only simple mind that does not harmonize with the meaningful and colorful life. His factory, fortune, ambition and life-style do not appeal to Isabel's freedom at all. So in the end, she rejects Caspar Goodwood's proposal, though of course the motive of sexual fear is very obvious, Isabel is above all aware that Caspar's idea of freedom is at odds with her own, that it would indeed nullify her very concept of herself. For Caspar Goodwood, freedom means that a woman deliberately made to suffer is justified in anything in life. However, for Isabel, freedom means that a woman that has made herself responsible for her own suffering has only "one straight path" to follow the wide but painful path of authenticity [4].

Isabel's second suitor is an English gentleman Lord Warburton. He stands for the traditional aristocratic culture of England and has a higher social status. Ralph praises him as: "He occupies a position that appeals to my imagination. Great responsibilities, great opportunities, greats consideration, great wealth, great power, a natural share in the public affairs for a great country".[3] So he is the ideal husband for every young girl just as Henry James' saying that: ninety-nine percent of young girls want to become Lady Warburton. However, Isabel turns him down. She feels that: "she had never yet known a personage, there had been no personage, in this sense, in her life; there was probably none such at all in her native land" [3]. So, when the 
possibility of admiration by a personage represented, to her, it is an aggression almost to the degree of an affront, quite to the degree of an inconvenience. "When she had thought of individual eminence she had thought of it on the basis of character and wit-of what one might like in a gentleman's mind and in his talk" [3]. However, Lord Warburton has been living in the old world for long time and has experienced so many complicated failure and hardships that he forms a kind of complicated idea of life. She refuses Lord Wurburton, not because he seeks his own salvation in her, his cure by interest, but rather because marriage to him would not satisfy her greed for experience, her freedom to see and feel and do [5]. Lord Wurburton stands for the great power and social status and that cannot "please her sublime soul" so, a kind of instinct tells her: refuse him and pursue freedom.

When Isabel refuses both Goodwood and Lord Wurburton these two excellent young men, we wonder what on earth kind of man can meet her requirement to please her sublime soul? In fact, she just wants to find a person staying in the same orbit with herself. In her mind, this person may be far from secular morality, and help her pursue artistic and spiritual freedom. Then Osmond comes, and "he is isolated from society and is expert in art and a paragon of taste" [6]. Osmond courts Isabel cleverly, appealing to her sense of the artist wonders of Europe, of which he seems to be a fine judge. She even feels so fortunate that she is so courageous to marry a poor man. She ignores his disadvantages: "No property, no title, no honors, no houses, nor land, nor position, nor reputation, nor brilliant belongings of any sort" [3]. But it is the very absence of all these things that please her. She tells Ralph proudly that: "Mr Osmond makes no mistakes. He knows everything, he understands everything, he has the kindest, gentlest, highest spirit!" [3] Can't help considering him as the prince in the dream, she decides to marry him and devote herself whole-heartedly.

Actually, what Isabel loves is not the real Osmond but an idealized Osmond. She beautifies his poverty and loneliness. Loving her own freedom, she forgets that liberty is often won at the expense of the freedom of others. Isabel in her sense of her own absoluteness, nourishes a delusion that one can play God or Goddess - if one has enough wealth and a few generous opportunities. So, since the power must seek power, and then the absolutism in the girl is gratified only by a match with another absolutist. Gilbert Osmond remarks at one moment that it is his unattainable ambition to be the Emperor of all the Russia, or perhaps the Pope. Since he cannot wield world-shaking power, he makes himself a petty tyrant. Osmond regards Isabel as an opportunity to create a work that will flatter himself and be the best testimony to his taste. He regards her intelligence as a silver plate he will heap with fruit to decorate his table. Her talk will be for him "a sort of served dessert." [2]. Then two kinds of egotism: freedom and tyranny meet conflict. An ideal of freedom and equality hedged with historical blindness and pride; a self-interest which often talks generous form; a sense of hurt when this generosity is seen as a wielding of power. As Osmond's wife, Isabel recognizes that she is a piece property, and her marriage becomes a tragedy.

\section{ISABEL'S FAILURE IN CROSS- CULTURE COMMUNICATION}

The Portrait of A Lady also deals with the crossculture communication. In the novel, two groups of people: American and European show an inevitable conflict through communication. Although many problems occur to the single person, in fact, many obstacles and misunderstandings all have something to do with the cultural discrepancy and certain kind of culture decides people's distinctive life style.

American people respect individuality and instead of those old conventions they pay only more attention to the efficiency. They have their own ideology, faith, idea of value, and distinct attitude towards the surroundings. Individuality becomes the most important factor in the American culture. This kind of character is best expressed in Isabel and because of which she chooses a false spouse and a tragic marriage.

Isabel, like other American girls, wants to go abroad to see the world, especially the old Europe. She is an idealist and full of romantic ideas in mind. The purpose she comes to Europe is to judge what she has seen and to choose and decide on her own. She shows model American characteristics: sincere, frank, independent and pursuing self-esteem. She knows that different nations have different life styles, so as an American newly arrived in Europe, her fate lies suspended between all possibilities. [7] However, in a sense, this lays the obstacles in the cross-culture communication.

Although Isabel constantly reminds herself that the purpose to go abroad is to make acquaintance with more people, to know well of the European society, yet the deep American cultural concept always makes her keep a kind of alertness to everything. Isabel hates the English class system and cannot imagine her belongings to any English class. So, we can see that toward everything around herself, even though Isabel does not hold the total negative point of view, yet she cannot understand even comprehend it. The failure of marriage is the best example for her in the cross-culture communication.

Lord Warburton is a model English gentleman: noble, handsome, rich and he is the ideal husband for those English girls. When Warburton makes proposal to Isabel, she also feels an irresistible appeal. She likes his gentle address - which is rooted from the old civilization, but unfortunately that she considers him a 
"model of English". [3] So, she cannot marry him. America gives Isabel her ideal of independence on which she prides herself, which makes Isabel cannot accept Lord Warburton's social status and family background. Then she frightens and shrinks. She is afraid of being locked in the marital cage. The cultural conflicts break up their further relationship and they cannot go into the marriage at last. In fact, Lord Warburton does not have too much superiority in himself, however, Isabel still treats him as a strange English gentleman because he stands for the English politics and culture. When they meet again in Isabel's home and Isabel is deeply immersed in the marriage agony, Lord Warburton shows his love toward her again. Although Isabel knows that his love is sincere, yet deep-rooted cultural concept promotes her to turn him down again.

Isabel always matches Lord Warburton with his political reputation and noble social status and family background. His cultural connotation frightens this independent American girl and to her the marriage with him will have the obstacles of communication. So, when Osmond comes to her, Isabel is so familiar as if she finds an intimate in this strange continent that she accepts immediately. Isabel can draw on no traditional wisdom that she finds Osmond belongs to none of those English classes and does not have those old conventions and customs. He is isolated from the society and only takes care of his little daughter. Expert in art and paragon of taste shows a kind of innate artist. This meets Isabel's requirement: a mixture of both American demeanour and European culture. Lord Warburton's cultural connotation is refused but $\mathrm{Mr}$ Touchett' inheritance to Isabel promotes an unfortunate marriage. Due to the opposition to the English hierarchy system, Isabel considers unearned income as a shame, so the given money becomes a burden and makes her shameful before Osmond. Wealth is suggested as a cause of boredom, and then marriage is proposed as a cure. In fact, Osmond marries her just for the money. The inveterate cultural concept makes her dispose of the money. She is full of imagination of life and her cousin Ralph wants her to gain the best opportunities, hoping "she is free and her being rich will keep her from marrying for money" [3]. She can go everywhere she likes and pursue the freedom and enjoy life. So, Ralph "put a little wind in her sails" [3]. and "put money in her purse" [3]. Unfortunately, because of the cultural divergence, the generous help becomes the chief criminal to the tragedy. After accepting the inheritance, Isabel has never thought how to fulfil the requirement of her imagination with the money. When Osmond comes to her, she assures he is entitled to this money, her wealth will endow Osmond's quiet life, and mistakenly thinks no money and no social status is liberty. Osmond is after all an American, and he knows well of American culture and know an innocent American girl like Isabel may have the certain idea of life. So, he caters to her liking, encourage her to pursue the pure freedom. So, what Isabel loves is not Osmond's property, but the nonentity disguised as independence. At last, although she knows Osmond is selfish, hypocritical, mean, vicious, and degenerated, and Lord Warburton and Goodwood still love her, she returns to Rome. She respects the old civilization of Europe, but cannot avoid cultural conflicts. She makes herself many excuses for returning and would rather bear the tragic marriage than accept the foreign culture. Isabel associates with the American traits of moral optimism and love of individual freedom but without caution in the face of evil. Thus, an intelligent, attractive girl comes across the marriage with the wrong person, and she becomes the great loser in the cross-culture communication.

Isabel is the first modern American girl to have her portrait hung in the international gallery. Her portrait hangs in the wall and she looks at us with her clear and gray eyes. Her intensity and luminous idea of the sacredness of the self, her insistence upon her sovereignty gives us a deep impression, but her marital tragedy leaves us a great pity.

With the double-folded characters, she is not conscious of the potential danger: her confidence gives her great charm but also traps her into conceit; her independence permits her to choose but also leads her to arbitrariness; her imagination gives her a beautiful dream, which is smashed in the cruel reality. She has only a literal understanding of marriage, so mistakenly thinks that to pursue spiritual freedom is the sublime ideal without needs of material. The ignorance of materialism and the pursuit of extreme freedom bring her marriage to bay. As an American girl, she respects the European ancient civilization, but refuses to tolerate and comprehend some certain cultural concepts. So, she fails in the mutual communication and returns to the miserable marriage life.

\section{CONCLUSION}

The Portrait of A Lady describes Isabel's sacred quest for ideal marriage and her failure, truthfully expresses Henry James' idea about marriage and reveals the difference between ideal and reality. He highly praises Isabel's strong belief and persistent quest but shows how difficult this quest is in the real world as well. Marital affairs are eternal for human society and these tragic factors may leave a glimpse of light to choose and maintain a wise marriage.

\section{REFERENCES}

[1] A. Bellringer, Henry James, Macmillan Press, 1988.

[2] L. Edel, The Portrait of A Lady, New York: Chelsea 1976. 
[3] H. James, The Portrait of A Lady, Shanghai: Shanghai Foreign Language Education Press, 2002.

[4] I. Maria, Isabel's Freedom: The Portrait of A Lady. In H. Bloom (Eds.) Contemporary Literature Criticism, New York: Chelsea House Publishers, 1987.

[5] W. Grass, The High Brutality of Good Tension. In H. Bloom (Eds.) The Critical Perspective, New York: Chelsea, 1989.

[6] V. Kinoian, Henry James the Portrait of A Lady, Simon \& Schuster. 1997.

[7] D. Morse, American Romanticism, Macmillan Press, 1983. 